\title{
Fragmentation, fiber separation, decomposition, and nutrient release of secondary-forest biomass, mechanically chopped-and-mulched, and cassava production in the Amazon
}

\author{
José Miguel Reichert ${ }^{\mathrm{a}}$, Miriam Fernanda Rodrigues ${ }^{\mathrm{a}, *}$, Clóvis Moisés Priebe Bervald ${ }^{\mathrm{b}}$, \\ Gustavo Brunetto ${ }^{\mathrm{a}}$, Osvaldo Ryohei Kato ${ }^{\mathrm{c}}$, Mauro Valdir Schumacher ${ }^{\mathrm{a}}$ \\ a Universidade Federal de Santa Maria [Federal University of Santa Maria] (UFSM), Santa Maria, RS, Brazil \\ b GSI Brazil, Chapada dos Guimarães-MT, Brazil \\ c EMBRAPA Eastern Amazon, Belém, PA, Brazil
}

\section{A R T I C L E I N F O}

\section{Article history:}

Received 18 October 2014

Received in revised form 6 February 2015

Accepted 11 February 2015

Available online 25 February 2015

\section{Keywords:}

Mechanized chopping of biomass

mulch

soil chemical properties

secondary humid forest vegetation

Manihot esculenta Crantz

\begin{abstract}
A B S T R A C T
No-tillage planting in mechanically-chopped secondary-forest seeks to replace slash-and-burning agriculture. We evaluated the effect of horizontal (HC) and vertical (VC) chopping-and-mulching mechanisms on vegetation fragmentation and decomposition rate and nutrient release from chopped residue, and on cassava production in eastern Amazon. Chopped-and-mulched residue was classified into four residue-size $\left(\mathrm{Fs}_{1}=1-7, \mathrm{Fs}_{2}=7-25, \mathrm{Fs}_{3}=25-35\right.$, and $\left.\mathrm{Fs}_{4}=>35 \mathrm{~mm}\right)$ and six residue-type (with husk/ bark - WB, partially chopped - PC, compact - C, partially shredded into fibers - PS, completely shredded into fibers - CS, and formless residue - F) classes. In litter-bags, residual dry matter (DM) was determined at five different days after chopping-and-mulching and residue distribution on soil surface (DAD), whereas release of $\mathrm{N}, \mathrm{P}, \mathrm{K}, \mathrm{Ca}$, and $\mathrm{Mg}$ was evaluated at four days. Residues-size and -type classes showed similar decomposition behavior, with a reduction of approximately $60 \%$ of initial DM at 90 DAD. Nevertheless, reduction in DM was slow, where 52 days are necessary for half of labile residue to be decomposed, with part of labile and recalcitrant residue remaining on soil surface. DM and nutrients in residue reduced over time. DM was $25 \%$ for residues-size classes for HC, $20 \%$ for VC, and $26 \%$ for residuetype classes, on average, at 300 DAD. Nutrients remaining in residues at 300 DAD were $26 \%$ and $27 \%$ of N, $26 \%$ and $22 \%$ of $\mathrm{P}, 29 \%$ and $22 \%$ of $\mathrm{K}, 16 \%$ and $15 \%$ of $\mathrm{Ca}$, and $17 \%$ and $23 \%$ of $\mathrm{Mg}$, respectively for $\mathrm{HC}$ and $\mathrm{VC}$. Release of nutrients was, generally, greater for smaller residue-size classes, similar between choppingand-mulching mechanisms, and did not affect cassava yield.
\end{abstract}

(c) 2015 Elsevier B.V. All rights reserved.

\section{Introduction}

Biomass management in open areas is done mainly by means of prescribed fires. However, fire was shown to produce degradation of soils and vegetation (Guénon et al., 2013) and intense soil and water erosion losses (Cerdà, 1998a,b,b). The effect of fire disappear only some years after the fire (Cerdà and Lasanta, 2005; Lasanta and Cerdà, 2005), and mulching is a good strategy to reduce soil and

\footnotetext{
* Corresponding author. Tel.: +55 55 32208918; fax: +55 5532208295 .

E-mail addresses: reichert@ufsm.br (J.M. Reichert),

miriamf_rodrigues@yahoo.com.br (M.F. Rodrigues), bervaldgsibrasil@hotmail.com (C.M.P. Bervald), brunetto.gustavo@gmail.com (G. Brunetto),

osvaldo.kato@embrapa.br (O.R. Kato), mvschumacher@gmail.com

(M.V. Schumacher)
}

water losses after the fire (Prats et al., 2013). The use of other managements is necessary and within them the use of chipped biomass is being found useful, such as Lee et al. (2013) found in road embankments, Jiménez et al., (2013) in afforested land, GarcíaOrenes et al. (2012) and Tejada and Benítez (2014) on agriculture land, or Milder et al. (2012) and Mukhopadhyay and Maiti (2014).

Soil management systems traditionally used in eastern Amazon consist of slashing-and-burning of secondary-forest that develops in fallows period between agricultural crops, with further soil turnover for planting (Denich et al., 2005; Béliveau et al., 2009). Soil surface remains more exposed to raindrop impact, which leads to soil degradation and greater soil and water losses through surface runoff (Farella et al., 2001; Davidson et al., 2008). There is also greater risk of accidental fires (Ruivo et al., 2007), greenhouse gas emissions (Davidson et al., 2008), loss of nutrients through leaching (Sommer et al., 2004; Béliveau et al., 2009), soil organic 
matter oxidation (Davidson et al., 2008), and consequent reduction in cation exchange capacity (CEC) (Farella et al., 2007; Béliveau et al., 2009; Adeniyi 2010). Further, after fires there is dispersion of clays with reduction in aggregate stability and increase in soil bulk density (Braz et al., 2013), increase in soil surface temperature (Ferreira et al., 2002), and greater moisture variations from increased solar radiation on soil surface layer (Cochrane and Sanchez, 1982).
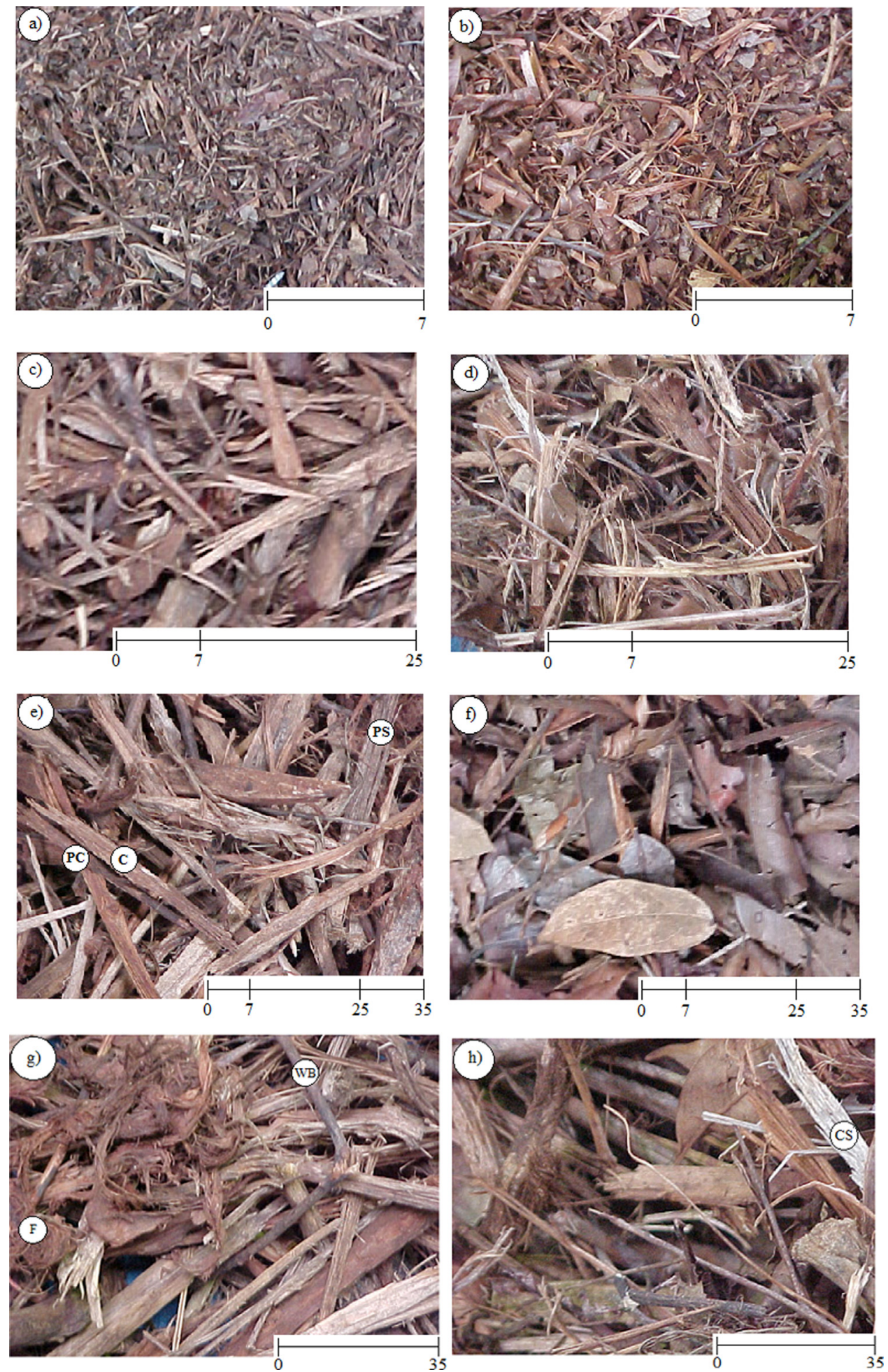

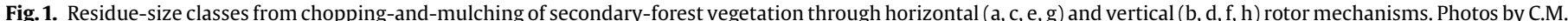
P. Bervald.

$\mathrm{Fs}_{1}=1-7 \mathrm{~mm}$ ( $\mathrm{a}$ and $\mathrm{b}$ ), $\mathrm{Fs}_{2}=7-25 \mathrm{~mm}$ (c and d), $\mathrm{Fs}_{3}=25-35 \mathrm{~mm}$ (e and f), and $\mathrm{Fs}_{4}=>35 \mathrm{~mm}(\mathrm{~g}$ and $\mathrm{h}$ ).

Numbers on scale bars are in $\mathrm{mm}$.

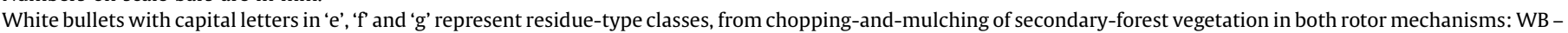
with bark, PC - partially chopped, C - compact, PS - partially shredded, CS - completely shredded, and F-formless. 
Thus, traditional secondary-forest management with burning leads to unsustainable cropping systems (Hölscher et al., 1997a,b; Sommer et al., 2004), and should not be recommended (Kanashiro and Denich, 1998).

One alternative to traditional slash-and-burn management of secondary-forest is managing standing vegetation to build up soil surface mulch (Kato et al., 2002). In such, special equipment is required for chopping-and-mulching the secondary-forest vegetation (Reichert et al., 2014). Two different mechanisms have been tested: one uses hammer heads at high revolution that crush vegetation up to $30-\mathrm{cm}$ in diameter, where two passes are needed to completely chop up biomass and shred wood material (Bervald et al., 2007); whereas the second uses circular saws and helices (helical knives) to cut off and chop up standing vegetation, where only one pass is necessary to completely chop up wood trunks less than 10-cm in diameter (Denich et al., 2004).

During decomposition of secondary-forest chopped vegetation deposited on soil surface, organic carbon (C) is used as energy source by microbial population, a portion of which is released as $\mathrm{CO}_{2}$ to atmosphere. Nutrients like nitrogen $(\mathrm{N})$, phosphorus $(\mathrm{P})$, potassium $(\mathrm{K})$, calcium $(\mathrm{Ca})$ and magnesium $(\mathrm{Mg})$ contained in the residues are partially released to soil, thus increasing their availability and uptake by plants such as cassava (Manihot esculenta Crantz), increasing growth and production of dry matter and roots (Cardoso Júnior et al., 2005; Pypers et al., 2012).

Residue decomposition and nutrient release are dependent on degree-of-fragmentation and residue exposure to edaphic and climatic conditions. Further, edaphic fauna diversity (Liao et al., 2006; Santos et al., 2008), residue chemical composition (especially cellulose, lignin, and polyphenols contents), and $\mathrm{C} / \mathrm{N}$ ratio (Vasconcelos and Laurance, 2005; Auer et al., 2007; Barlow et al., 2007) also affect the decomposition process. Residues with greater lignin content and $\mathrm{C} / \mathrm{N}$ ratio decompose and release nutrients to soil in a slower and more gradual process (Vasconcelos and Laurance, 2005; Auer et al., 2007), compared to residues with lower lignin content, greater cellulose content and lower $\mathrm{C} / \mathrm{N}$ ratio (Auer et al., 2007).

For efficient and environmentally sound agricultural production in naturally fragile soils of the Amazon, information is still in an initial stage regarding residue decomposition and nutrient release from secondary-forest residues (Cattanio et al., 2008), whether with a defined degree-of-fragmentation or shredded into fibers.

Our hypothesis was that "different chopping-and-mulching mechanisms for secondary-forest vegetation management in the Amazon provide residues of different sizes and fiber separation degrees, where smaller, fiber-separated residue show greater decomposition rate and nutrient release to soil for improved cassava yield". We evaluated the effect of horizontal and vertical chopping mechanisms to chop-and-mulch secondary-forest on the decomposition rate and nutrient release from chopped residues, and on cassava production in sandy soil of the eastern Brazilian Amazon.

\section{Materials and methods}

\subsection{Study area}

The study was conducted in municipality of Igarapé-Açu, in northeastern Pará $\left(01^{\circ} 11^{\prime} 37^{\prime \prime} \mathrm{S}\right.$ and $\left.47^{\circ} 35^{\prime} 43^{\prime \prime} \mathrm{W}\right)$ in eastern Brazilian Amazon. Climate is tropical monsoon (Am) (Köppen classification - Alvares et al., 2013), with annual rainfall between 2000 and $3000 \mathrm{~mm}$, and average annual temperature of $24.9{ }^{\circ} \mathrm{C}$ (Diniz, 1991). The soil is classified as Oxisols (Soil Taxonomy USDA, 1999) and Latossolo Amarelo (Brazilian Soil Classification System - EMBRAPA, 2006). Soil textures of soil layers in different chopped management systems are sand $(0.00-0.10 \mathrm{~m})$, loamy sand $(0.10-0.30 \mathrm{~m})$, and sandy loam $(0.30-0.50 \mathrm{~m})$. Most of the soil pores are from $0.30-0.05 \mathrm{~mm}$ (large pores) for all the layers, responsible for rapid water drainage at low suctions and low water storage capacity.

\subsection{Chopping mechanisms}

The area under study ( 1 ha) was under original secondary-forest maintained fallow for a period of 4 years, when a tree-shrub vegetation through natural regeneration developed. In half hectare, secondary-forest vegetation was chopped with a horizontal rotor mechanism (HC) (Supplementary file 1), while on the other half vegetation chopping was done with a double vertical rotor mechanism (VC) (Supplementary file 2).

Supplementry material related to this article found, in the online version, at http://dx.doi.org/10.1016/j.agee.2015.02.005.

For the HC, vegetation ( $36.46 \mathrm{Mg} \mathrm{ha}^{-1}$ ) was chopped using a mechanized unit composed of a universal shredding device with a horizontal rotor system coupled to a tractor (Supplementary file 1 ). The $120-\mathrm{kW}$ tractor, reversible steering in the backward drive operating process, Nokia 20.8-38 model rear tyres, and $7.50-\mathrm{Mg}$ weight exerted $60-\mathrm{kPa}$ total pressure on the soil surface, as calculated Wästerlund (1994) equation. Standing vegetation was chopped in two operations: (i) the first pass was in reverse to knock down vegetation, while the second pass was in normal operating direction for chopping up plant residue.

For the VC, vegetation (44.44 $\mathrm{Mg} \mathrm{ha}^{-1}$ ) chopping was performed with a mechanized unit called Tritucap, which has a double vertical rotor system coupled to a tractor (Supplementary file 2). The effective width of the Tritucap was $1950 \mathrm{~mm}$ and each rotor weighed $400 \mathrm{~kg}$, for a total machine weight of $1300 \mathrm{~kg}$ (Bervald et al., 2007). Chopping of the vegetation was carried out in only one operation.

\subsection{Sampling and evaluation of the chopped residue}

Chopping and mulching of secondary-forest maintained fallow for 4 years provided $60 \%$ soil coverage by chopped residues for both systems. The mean thickness of chopped residue was $4.9 \mathrm{~cm}$ for the VC and $5.0 \mathrm{~cm}$ for the HC. For each chopping mechanism (VC and $\mathrm{HC})$, a $0.20 \times 10.0 \mathrm{~m}\left(2.00 \mathrm{~m}^{2}\right)$ strip was marked off, an area corresponding to four machine-passes for soil sampling. Three samples of chopped residue were collected at random from each strip for quantitative classification of residue fragmentation degree, and three samples for qualitative classification of fiber separation degree.

\subsubsection{Residue-size classes}

Three samples of chopped residues, taken from each chopping mechanism ( $\mathrm{HC}$ and $\mathrm{VC}$ ), were screened through a set of four sieves with of $35,25,7$, and $1-\mathrm{mm}$ mesh openings. Two measurements of diameter and one of length were made and residues were divided up into four chopped residue-size classes (Fs): $\mathrm{Fs}_{1}(1-7 \mathrm{~mm}), \mathrm{Fs}_{2}(7-25 \mathrm{~mm}), \mathrm{Fs}_{3}(25-35 \mathrm{~mm})$, and $\mathrm{Fs}_{4}$ $(>35 \mathrm{~mm}$ ) (Fig. 1). For the VC, distribution of the residues to each class was, by dry volume, $17 \%\left(\mathrm{Fs}_{1}\right), 39 \%\left(\mathrm{Fs}_{2}\right), 16 \%\left(\mathrm{Fs}_{3}\right)$, and $28 \%$ $\left(\mathrm{Fs}_{4}\right)$ while, for $\mathrm{HC}$, the distribution was $43 \%\left(\mathrm{Fs}_{1}\right), 21 \%\left(\mathrm{Fs}_{2}\right), 9 \%$ $\left(\mathrm{Fs}_{3}\right)$, and $27 \%\left(\mathrm{Fs}_{4}\right)$.

For decomposition analysis, five $50-\mathrm{g}$ samples of residue were taken from each Fs from the three samples collected in the field. A total of 60 samples per chopping mechanism were collected, with 15 samples per residue-size class of chopped fragments from HC and 15 samples per residue-size class from VC. Samples with $\mathrm{Fs}_{1}$ and $\mathrm{Fs}_{2}$ residues were placed in litter bags with $1.3-\mathrm{mm}$ mesh opening and dimensions of $0.15 \times 0.25 \mathrm{~m}\left(0.0375 \mathrm{~m}^{2}\right)$, whereas for 
$\mathrm{Fs}_{3}$ and $\mathrm{Fs}_{4}$ litter bags of $0.15 \times 0.35 \mathrm{~cm}\left(0.0525 \mathrm{~m}^{2}\right)$ and mesh opening of $1.3 \mathrm{~mm}$ were used in the field.

\subsubsection{Residue-type classes}

Three residues samples collected in the field for degree-offragmentation analysis were passed through a set of two sieves with mesh opening of 35 and $25 \mathrm{~mm}$ to obtain residues in the $\mathrm{Fs}_{3}$ (25-35 mm) size-class of chopped fragments from VC and from HC. These residue samples were mixed to obtain homogeneity and three combined sub-samples $(\mathrm{VC}+\mathrm{HC})$ were analyzed. The $\mathrm{Fs}_{3}$ class was chosen for residue-type classes for analysis since residues had more similar visual aspect.

These combined samples $(\mathrm{VC}+\mathrm{HC})$ were classified in six residue-type classes based on fiber separation (Fig. 1; Supplementary file 3) into (i) rounded residue, with the husk/bark around the entire surface of the fragments (with bark - WB); (ii) residue that remained with remnants of bark after chopper attack (partially chopped - PC); (iii) residue chopped in a regular manner, derived from chopping inner parts of secondary forest (compact - C); (iv) residue that underwent the action of chopping mechanisms derived from inner trunk, with little action of chopping mechanisms (partially shredded - PS) (Fig. 1e); (v) residue similar to partially shredded, but with a greater degree fiber separation brought about by shredding mechanisms (completely shredded - CS) (Fig. 1h); and (vi) residue consisting of totally irregular parts of shrubs, basically shoots and vines (formless - F) (Fig. 1g).

Supplementry material related to this article found, in the online version, at http://dx.doi.org/10.1016/j.agee.2015.02.005.

Afterwards, five 50-g residue samples were taken from each class from the three samples collected in the field for decomposition evaluation, which amounted to 90 samples $(\mathrm{VC}+\mathrm{HC})$, with 15 residue samples per size class. The samples were placed in litter bags with dimensions of $0.15 \times 0.35 \mathrm{~m}$ $\left(0.0375 \mathrm{~m}^{2}\right)$ and mesh opening of $1.3 \mathrm{~mm}$ for field decomposition analysis.

\subsubsection{Decomposition and nutrient release from chopped residue}

Sixty (60) litter bags of chopped residue-size classes from $\mathrm{HC}$, the 60 from VC, and the 90 from residue-type classes $(\mathrm{VC}+\mathrm{HC})$ were placed under the mulch resulting from chopping, between cassava plant rows, at $1.0-\mathrm{m}$ intervals to evaluate decomposition and nutrient release by means of sampling in given time intervals. These litter bags were fixed to soil using wood stakes of $0.5 \mathrm{~m}$ height to avoid possible displacement.

The litter bags were collected soon after ( 0 days) and at 30,90, 180 , and 300 days after distribution (DAD) of chopped residue on soil surface for determining residual DM. Nutrient release was evaluated soon after ( 0 days) and at 90 and 300 DAD. For each analysis period, three litter bags were collected from each chopped residue-size class, and five litter bags for samples residue-type class. On each collection date, residues were removed from litter bag and soil particles adhering to residues were removed with a brush. This residue was dried in a forced aircirculation laboratory-oven at $65^{\circ} \mathrm{C}$ and residual DM was determined.

Residues were ground in a Wiley type mill and screened through a 30-mesh sieve. Total organic C and N, P, K, Ca, and Mg contents were determined (Tedesco et al., 1995). Total organic C was analyzed by the Walkley-Black method (EMBRAPA, 1997); N was determined by Kjeldahl method, in which the $\mathrm{NH}_{4}{ }^{+}$produced in digestion with $\mathrm{H}_{2} \mathrm{SO}_{4}$ is distilled in a strongly alkaline medium; available $\mathrm{P}$ and exchangeable $\mathrm{K}$ were extracted with Mehlich 1 solution $\left(0.05 \mathrm{~mol} \mathrm{~L}^{-1} \mathrm{HCl}+0.0125 \mathrm{~mol} \mathrm{~L}^{-1} \mathrm{H}_{2} \mathrm{SO}_{4}\right)$ and measured by spectrophotometry and flame photometry, respectively; and exchangeable Ca and Mg contents were extracted with $1 \mathrm{~mol} \mathrm{~L}^{-1}$ $\mathrm{KCl}$ and measured with an atomic absorption spectrophotometer (Tedesco et al., 1995).

\subsection{Cassava growing}

The Inhá cassava variety was planted in no-till planting system in chopped secondary-forest area by only opening a planting hole soon after chopping, without any complementary fertilization, at $1.0 \times 1.0-\mathrm{m}$ spacing. After ten months of cassava growth, plant height and crop biomass and yield were evaluated, by harvesting a total of 18 plants per treatment.

\subsection{Statistical analysis}

A non-linear regression model $\mathrm{RDM}=A e^{-k t}+(100-A)$ (Wieder and Lang, 1982) was fit to the observed results of residual dry matter percentage, in which RDM is percentage of residual dry matter after a period of time $t$ in days after distribution of residues on the soil surface; $A$ is labile compartment (more easily decomposable); $(100-A)$ is recalcitrant compartment; and $k$ is constant of decomposition. The model considers that dry matter of residues may be divided into two compartments and reduces exponentially at constant rates. The first fraction is transformed at higher rates than the second, which is of more difficult decomposition (recalcitrant compartment).

The non-linear regression model $\mathrm{RN}=A e^{-k t}$ (Wieder and Lang, 1982) was used to fit the percentages of nutrients (N, P, K, Ca, and $\mathrm{Mg}$ ) remaining in dry matter, in which $\mathrm{RN}$ is percentage of residual nutrient after the period of time $t$, in days after distribution of the residues on the soil surface; $A$ is initial percentage of the nutrient in the dry matter; and $k$ is constant of decomposition.

Once $k$ values were determined half-life was calculated $\left(t^{1 / 2}=0.693 / k_{(a, b)}\right)$ (Paul and Clark, 1989), which expresses the

\section{Table 1}

Parameters of fitted model RDM $=A e^{-k t}+(100-A)$ to values of residual dry matter and half-life of residue-size and residue-type classes from mechanisms for chopping-and-mulching secondary-forest in an area cropped to cassava.

\begin{tabular}{lllllll}
\hline $\begin{array}{l}\text { Size } \\
(\mathrm{mm})\end{array}$ & Class $^{\mathrm{a}, \mathrm{b}}$ & $\begin{array}{l}A \\
(\%)\end{array}$ & $\begin{array}{l}100-A \\
(\%)\end{array}$ & $\begin{array}{l}k \\
\left(\text { day }^{-1}\right)\end{array}$ & $\begin{array}{l}t^{1 / 2} \\
(\text { days })\end{array}$ & $r^{2}$ \\
\hline $\mathrm{HC}^{\mathrm{c}}$ & & & & & & \\
$1-7$ & $\mathrm{Fs}_{1}$ & 87.6 & 12.4 & 0.0133 & 52 & 0.96 \\
$7-25$ & $\mathrm{Fs}_{2}$ & 84.5 & 15.5 & 0.0136 & 51 & 0.93 \\
$25-35$ & $\mathrm{Fs}_{3}$ & 85.6 & 14.4 & 0.0141 & 49 & 0.95 \\
$>35$ & $\mathrm{Fs}_{4}$ & 85.2 & 14.8 & 0.0133 & 52 & 0.96 \\
& & & & & & \\
$\mathrm{VC}$ & & & & & & \\
$1-7$ & $\mathrm{Fs}_{1}$ & 89.0 & 11.0 & 0.0132 & 53 & 0.96 \\
$7-25$ & $\mathrm{Fs}_{2}$ & 88.3 & 11.7 & 0.0140 & 50 & 0.97 \\
$25-35$ & $\mathrm{Fs}_{3}$ & 94.2 & 5.8 & 0.0115 & 60 & 0.99 \\
$>35$ & $\mathrm{Fs}_{4}$ & 85.1 & 14.9 & 0.0136 & 51 & 0.94 \\
& & & & & & \\
Fiber separation $(\mathrm{HC}+\mathrm{VC})$ & & & & & \\
$25-35$ & $\mathrm{WB}$ & 84.7 & 15.3 & 0.0138 & 50 & 0.95 \\
$25-35$ & $\mathrm{PS}$ & 80.5 & 19.5 & 0.0134 & 52 & 0.94 \\
$25-35$ & $\mathrm{PC}$ & 83.5 & 16.5 & 0.0141 & 49 & 0.95 \\
$25-35$ & $\mathrm{C}$ & 87.5 & 12.5 & 0.0128 & 54 & 0.95 \\
$25-35$ & $\mathrm{CS}$ & 84.7 & 15.3 & 0.0135 & 51 & 0.95 \\
$25-35$ & $\mathrm{~F}$ & 87.3 & 12.7 & 0.0126 & 55 & 0.94 \\
\hline
\end{tabular}

a Residue-size classes: $\mathrm{Fs}_{1}=1-7 \mathrm{~mm}, \mathrm{Fs}_{2}=7-25 \mathrm{~mm}, \mathrm{Fs}_{3}=25-35 \mathrm{~mm}$, and $\mathrm{Fs}_{4}=$ $>35 \mathrm{~mm}$.

b Residue-type classes: WB - with bark, PC-partially chopped, PS-partially shredded, CS - completely shredded, C-compact, F-formless.

${ }^{c} \mathrm{HC}$ : Chopping-and-mulching of secondary forest with the horizontal rotor mechanism; VC: chopping-and-mulching of the secondary forest with the vertical rotor mechanism; A: labile compartment of the dry matter (easily decomposable); $(100-A)$ : recalcitrant compartment of the dry matter; $k$ : constant of decomposition of the dry matter of the labile compartment; $t^{1 / 2}$ : half-life; $r^{2}$ : coefficient of determination. 

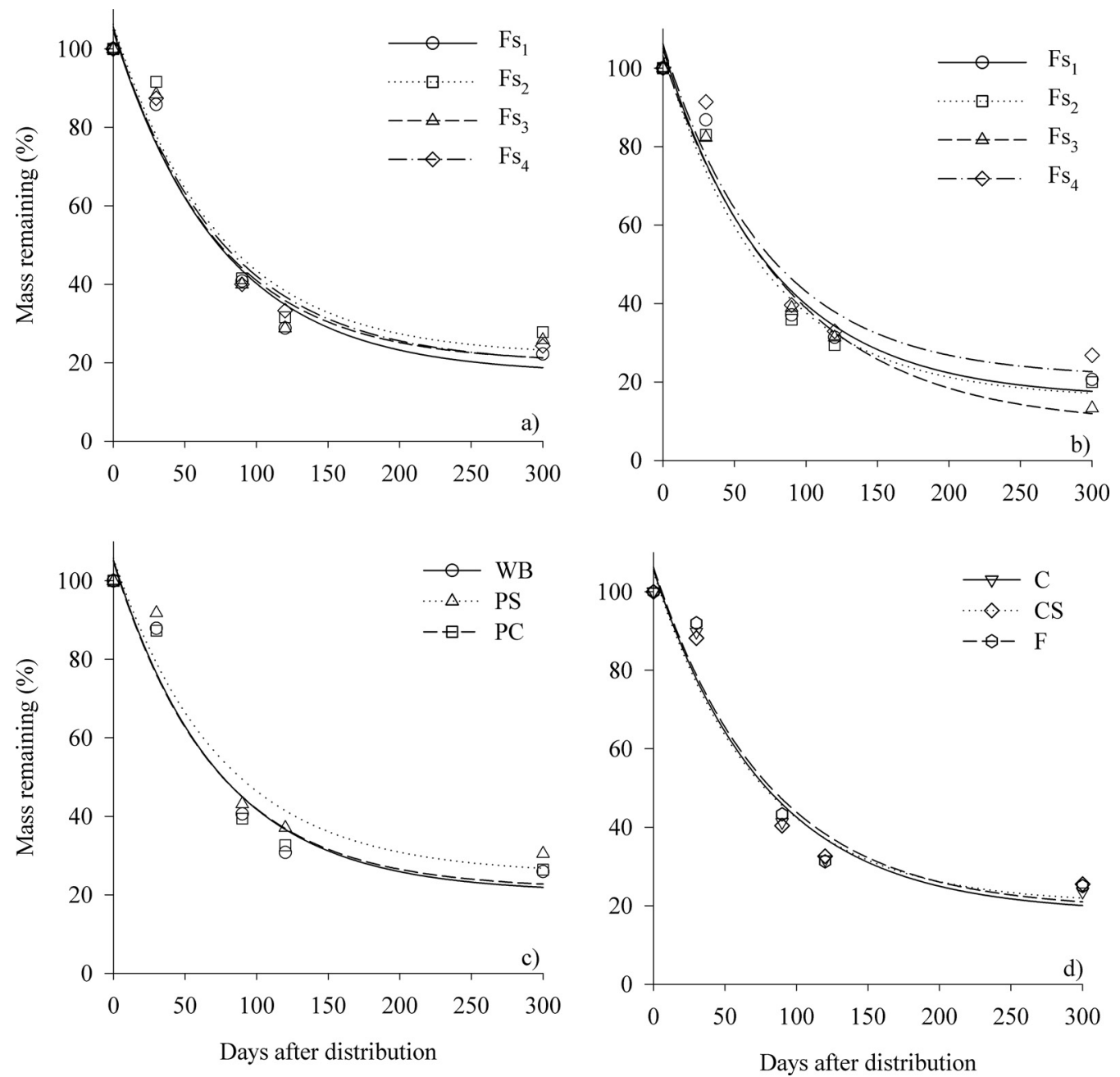

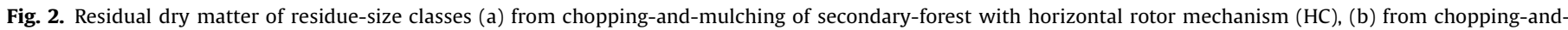
mulching of secondary-forest with vertical rotor mechanism (VC) and (c and d) from residue-type classes (HC+VC) in an area cropped to cassava.

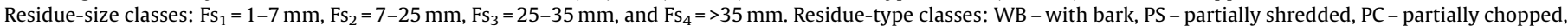
$\mathrm{C}$ - compact, CS - completely shredded, $\mathrm{F}$ - formless.

time period necessary for half of the residues decompose or when half of the nutrients contained in residue is released.

Cassava parameters were subjected to analysis of variance (F-test) and mean values were compared by Tukey test at $5 \%$ significance, using Statistical Analysis System software (SAS, 1990).

\section{Results and discussion}

\subsection{Decomposition of residues and $C / N$ ratio}

Residual dry matter (DM) of plant residues diminished over time and, on each collection date, was similar among residue-size classes $\left(\mathrm{Fs}_{1}, \mathrm{Fs}_{2}, \mathrm{Fs}_{3}\right.$, and $\left.\mathrm{Fs}_{4}\right)$ from $\mathrm{HC}$ (Table 1 and Fig. $2 \mathrm{a}$ ) and from VC (Table 1 and Fig. 2b), and from residue-type classes (WB, PS, PC, C, CS, and F) (Table 1 and Fig. 2c and d).

After an initial rapid rate the decline in DM slowed (Fig. 2). For $\mathrm{HC}$ residual DM at 90 days after distribution (DAD) was approximately $40 \%$ of the initial DM. At 300 DAD residual DM was near $25 \%$ (Fig. 2a). The more easily decomposable DM was, on average, $86 \%$ of the total initial DM (Table 1$)$. The half-life $\left(t^{1 / 2}\right)$ of residue-size classes ranged from $49\left(\mathrm{Fs}_{3}\right)$ to $52\left(\mathrm{Fs}_{1}\right.$ and $\left.\mathrm{Fs}_{4}\right)$ days (Table 1 ). However, at 300 DAD mean residual DM was greater than $14 \%$, which corresponds to DM of more slowly decomposable compartment. Thus, even at 300 DAD the soil still contained residues deposited on soil surface during chopping-and-mulching.

Reduction in residual DM over time in VC was similar to HC. Greatest reduction of residual DM was observed up to 90 DAD. However, at 30 and at 300 DAD residual DM of the smallest residue-size $\left(\mathrm{Fs}_{1}\right)$ was greater than for other treatments, 91 and $27 \%$, respectively (Fig. $2 \mathrm{~b}$ ). Residue $t^{1 / 2}$ ranged from $50\left(\mathrm{Fs}_{2}\right)$ to 60 $\left(\mathrm{Fs}_{3}\right)$ days among residue-size classes (Table 1$)$. At 300 DAD mean residual DM was greater than $11 \%$, which corresponds to DM of the most slowly decomposable compartment.

Comparing the two chopping mechanisms, at 300 DAD in VC residual $\mathrm{DM}$ of the smaller residue-size classes was $1.3\left(\mathrm{Fs}_{1}\right), 7.9$ $\left(\mathrm{Fs}_{2}\right)$, and $12.3\left(\mathrm{Fs}_{3}\right)$ percentage points less than for residues from $\mathrm{HC}$ (Fig. $2 \mathrm{a}$ and b). For greater residue-size class $\left(\mathrm{Fs}_{4}\right)$, residual DM for VC was $2.9 \%$ points greater than that observed for the same class from HC (Fig. 2a and b).

Residue DM reduction was more pronounced up to 90 DAD (Fig. 2c and d). Mean residual DM among residue-type classes was approximately $40 \%$ of initial DM. The easily decomposable DM was, on average, $84 \%$ of total initial DM (Table 1 ). At 300 DAD residual DM was 23.6\% (C), 25.9\% (WB), 30.5 (PS), 25.5 (CS), 25.0 (F), and $26.4 \%$ (PC) (Fig. 2c and d), values greater than $16 \%$ that corresponds to DM of most slowly decomposable compartment. Shortest $t^{1 / 2}$ 
was observed at 49 DAD for partially chopped residues (PC), while longest $t^{1 / 2}$ was at 55 DAD for formless residues (F) (Table 1 ).

Mean decomposition constant $(k)$ for the easily decomposable compartment was $0.0136 \mathrm{day}^{-1}, 0.0131 \mathrm{day}^{-1}$, and $0.0134 \mathrm{day}^{-1}$, for residue-size classes from $\mathrm{HC}$, from $\mathrm{VC}$, and from residue-type classes, respectively (Table 1 ). Lower $k$ values indicate that decomposition rate and nutrient release from surface residues is slower (Doneda et al., 2012).

For residue-size classes ( $\mathrm{Fs}_{1}$ to $\left.\mathrm{Fs}_{4}\right)$ from $\mathrm{HC}$ (Table 1 and Fig. 2a), from VC(Table 1 and Fig. 2 b), and from residue-type classes (HC + VC) (WB, PS, PC, C, CS, and F), reduction in residue DM over the 300 DAD occurred because of microbial activity and leaching of soluble compounds (Christensen et al., 1985; Musvoto et al., 2000), stimulated by rainfall and air and soil temperature increase (Espíndola et al., 2006). Nevertheless, during the decomposition process, labile compounds are more rapidly decomposed and, more slowly, recalcitrant compounds are decomposed (Fig. 2a-d) (Reinertsen et al., 1984; Hunt et al., 1988; Doneda et al., 2012). Cattanio et al. (2008) evaluated residue decomposition in the Amazon and also observed exponential pattern of residue weight

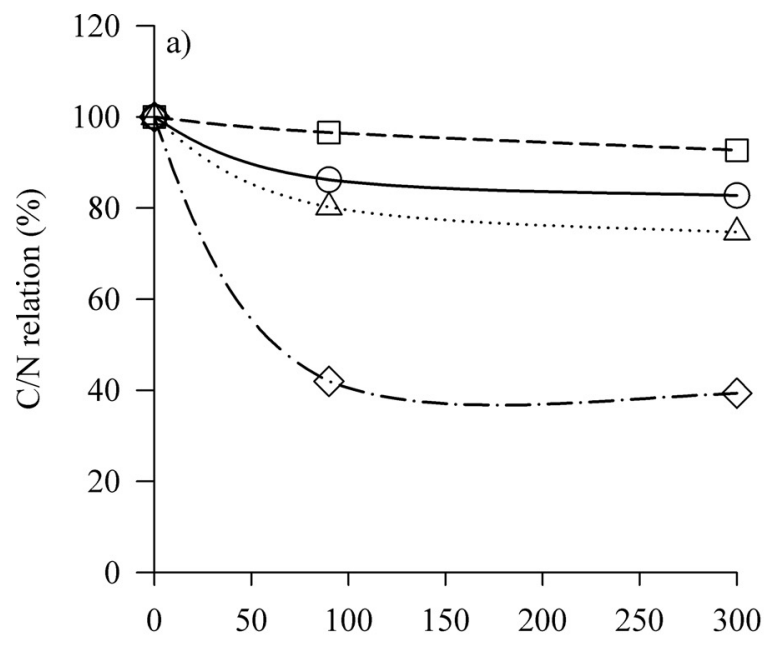

Days after distribution

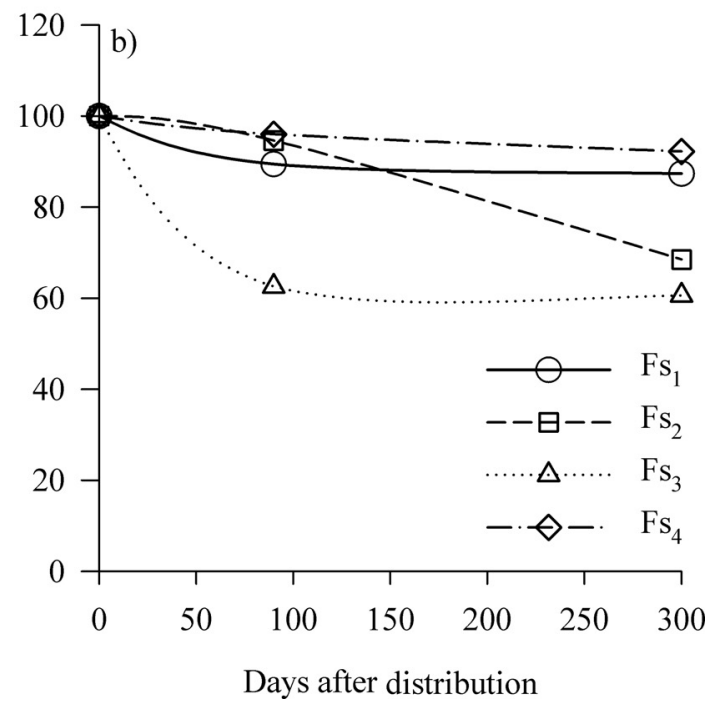

Fig. 3. Residual $\mathrm{C} / \mathrm{N}$ ratio in dry matter during decomposition of residue chopped with horizontal rotor mechanism (HC) (a) and vertical rotor mechanism (VC) (b) of chopping-and-mulching secondary-forest vegetation in an area cropped to cassava. Residue-size classes: $\mathrm{Fs}_{1}=1-7 \mathrm{~mm}, \mathrm{Fs}_{2}=7-25 \mathrm{~mm}, \mathrm{Fs}_{3}=25-35 \mathrm{~mm}$, and $\mathrm{Fs}_{4}=>35$ $\mathrm{mm}$. loss, which shows that residues contain labile and recalcitrant fractions, with different degrees of degradation resistance by microbial population.

Similar percentage of residual DM in each collection date for residues-size from $\mathrm{HC}$ and VC and from residues-type (HC+VC) would not be the expected decomposition behavior because, normally, less fragmented residues tend to have a lower specific surface area in contact with soil, which may diminish microbial activity decomposition rate, measured by residual DM (Hyvönen et al., 2000). Further, they state, for residues with same chemical composition, the more fragmented residues are decomposed more rapidly and are a source of nutrients in a shorter period of time, whereas concentration of nutrients in less fragmented residues is more important in the long-term, since there is an inverse correlation between residue constituents diameter and residues decomposition rate. However, the results of our study may be due to the fact that, with the exception of $\mathrm{Fs}_{4}$ in $\mathrm{HC}$ (Fig. 3a) and $\mathrm{Fs}_{3}$ in VC (Fig. 3b), residues of other residue-size and residue-type classes exhibited a similar $\mathrm{C} / \mathrm{N}$ ratio over the experimental period (Fig. $3 \mathrm{a}$ and $\mathrm{b}$ ). Further, residue $\mathrm{C} / \mathrm{N}$ ratio of all residue-size and type classes was greater than 20 in all sampling times (Fig. 3a and b). Thus, they are composed by residues with hindered microbial colonization since there is less $\mathrm{N}$ available for microbial tissue build up (Cattanio et al., 2008), which explains the similar values of residual DM over time. Cattanio et al. (2008) observed that, in addition to high quantity of organic $\mathrm{C}$ in relation to $\mathrm{N}$, low content of other nutrients in residues applied as soil surface mulch limits energy available to microorganisms.

Table 2

Parameters of fitted model $\mathrm{RN}=A e^{-k t}$ to observed values of residual nitrogen $(\mathrm{N})$, phosphorus $(\mathrm{P})$, potassium $(\mathrm{K})$, calcium $(\mathrm{Ca})$, and magnesium $(\mathrm{Mg})$ and half-life of residue-size and residue-type classes from mechanisms for chopping-andmulching secondary-forest in an area cropped to cassava.

\begin{tabular}{|c|c|c|c|c|c|c|c|c|}
\hline Class $^{\mathrm{a}}$ & $\begin{array}{l}A \\
(\%) \\
\mathrm{HC}\end{array}$ & $\begin{array}{l}k \\
\left(\text { day }^{-1}\right)\end{array}$ & $\begin{array}{l}t^{1 / 2} \\
\text { (days) }\end{array}$ & $r^{2}$ & $\begin{array}{l}A \\
(\%) \\
\text { VC }\end{array}$ & $\begin{array}{l}k \\
\left(\text { day }^{-1}\right)\end{array}$ & $\begin{array}{l}t^{1 / 2} \\
\text { (days) }\end{array}$ & $r^{2}$ \\
\hline \multicolumn{9}{|l|}{$\mathrm{N}$} \\
\hline $\mathrm{Fs}_{1}$ & 99 & 0.0105 & 66 & 0.96 & 96 & 0.0065 & 107 & 0.92 \\
\hline $\mathrm{Fs}_{2}$ & 99 & 0.0120 & 58 & 0.87 & 98 & 0.0035 & 196 & 0.99 \\
\hline $\mathrm{Fs}_{3}$ & 94 & 0.0057 & 121 & 0.84 & 98 & 0.0046 & 151 & 0.98 \\
\hline $\mathrm{Fs}_{4}$ & 93 & 0.0062 & 113 & 0.76 & 98 & 0.0087 & 80 & 0.96 \\
\hline \multicolumn{9}{|l|}{$P$} \\
\hline $\mathrm{Fs}_{1}$ & 100 & 0.0154 & 45 & 0.97 & 98 & 0.0063 & 111 & 0.97 \\
\hline $\mathrm{Fs}_{2}$ & 97 & 0.0085 & 82 & 0.89 & nd & nd & nd & nd \\
\hline $\mathrm{Fs}_{3}$ & 94 & 0.0041 & 169 & 0.86 & 100 & 0.0062 & 111 & 1.00 \\
\hline $\mathrm{Fs}_{4}$ & 95 & 0.0064 & 108 & 0.85 & 96 & 0.0050 & 140 & 0.94 \\
\hline \multicolumn{9}{|l|}{ K } \\
\hline $\mathrm{Fs}_{1}$ & 100 & 0.0189 & 37 & 0.94 & 100 & 0.0146 & 47 & 0.94 \\
\hline $\mathrm{Fs}_{2}$ & nd & nd & nd & nd & 98 & 0.0058 & 119 & 0.99 \\
\hline $\mathrm{Fs}_{3}$ & nd & nd & nd & nd & 107 & 0.0035 & 201 & 0.91 \\
\hline $\mathrm{Fs}_{4}$ & nd & nd & nd & nd & 98 & 0.0090 & 77 & 0.95 \\
\hline \multicolumn{9}{|l|}{$\mathrm{Ca}$} \\
\hline $\mathrm{Fs}_{1}$ & 99 & 0.0123 & 56 & 0.97 & 100 & 0.0164 & 42 & 0.90 \\
\hline $\mathrm{Fs}_{2}$ & 99 & 0.0108 & 64 & 0.95 & 100 & 0.0210 & 33 & 0.95 \\
\hline $\mathrm{Fs}_{3}$ & 98 & 0.0088 & 79 & 0.96 & 99 & 0.0093 & 74 & 1.00 \\
\hline $\mathrm{Fs}_{4}$ & 102 & 0.0039 & 179 & 0.99 & 99 & 0.0098 & 71 & 0.97 \\
\hline \multicolumn{9}{|l|}{$\mathrm{Mg}$} \\
\hline $\mathrm{Fs}_{1}$ & 100 & 0.0150 & 46 & 0.97 & 96 & 0.0069 & 100 & 0.88 \\
\hline $\mathrm{Fs}_{2}$ & 98 & 0.0100 & 69 & 0.91 & 96 & 0.0079 & 88 & 0.82 \\
\hline $\mathrm{Fs}_{3}$ & nd & nd & nd & nd & 99 & 0.0090 & 77 & 0.99 \\
\hline $\mathrm{Fs}_{4}$ & nd & nd & nd & nd & 98 & 0.0108 & 64 & 0.87 \\
\hline
\end{tabular}

HC: chopping-and-mulching of secondary-forest with horizontal rotor mechanism; VC: chopping-and-mulching of secondary-forest with vertical rotor mechanism; A: initial percentage of the nutrient in the dry matter; $k$ : constant of decomposition; $t^{1 /}$

2: half-life; $r^{2}$ : coefficient of determination; nd: not determined.

a Residue-size classes resulting from chopping-and-mulching $\mathrm{Fs}_{1}=1-7 \mathrm{~mm}$, $\mathrm{Fs}_{2}=7-25 \mathrm{~mm}, \mathrm{Fs}_{3}=25-35 \mathrm{~mm}$, and $\mathrm{Fs}_{4}=>35 \mathrm{~mm}$. 
Slow decomposition over time of a portion of the different residue-size classes and residue-type classes is desirable. At the end of first crop year, part of residues from chopped-vegetation should still remain on soil surface, contributing to raindrop kinetic energy dissipation, reduction in soil degradation (Farella et al., 2001; Davidson et al., 2008) and in surface runoff (Braz et al., 2013; Comte et al., 2012), and increase in soil total organic carbon (Bayer et al., 2004; Sommer et al., 2004).

\subsection{Residual nutrients in residues}

In residues from $\mathrm{HC}$, lower percentages of residual $\mathrm{N}$ over time were observed in largest residues-size classes $\left(\mathrm{Fs}_{1}\right.$ and $\left.\mathrm{Fs}_{2}\right)$, in relation to smaller residue-size classes $\left(\mathrm{Fs}_{3}\right.$ and $\mathrm{Fs}_{4}$ ) (Table 2). Residual $\mathrm{N}$ was similar among residue-size classes at 90 and at 300 DAD, with mean values of 35.1 and $26.1 \%$, respectively. The $t^{1 / 2}$ of $\mathrm{N}$ ranged from 58 to 121 days for $\mathrm{Fs}_{2}$ and $\mathrm{Fs}_{3}$, respectively, in which mean $k$ of residual $\mathrm{N}$ was $0.0086 \mathrm{day}^{-1}$ for all residue-size classes from HC (Table 2).

Residual $\mathrm{N}$ in VC was less for less residue-size classes $\left(\mathrm{Fs}_{4}\right)$; nevertheless, $\mathrm{Fs}_{4}$ did not exhibit expected decomposition behavior when taking into consideration the degree-of-fragmentation. At $90 \mathrm{DAD} \mathrm{Fs}_{4}$ had the lowest percentage of residual $\mathrm{N}$ (39.6\%), while the greatest was observed for $\mathrm{Fs}_{2}$ (67.9\%). The same behavior occurred at $300 \mathrm{DAD}$, in which lowest percentage of residual $\mathrm{N}$ was $17.4 \%$ for $\mathrm{Fs}_{4}$ and greatest was $36.3 \%$ for $\mathrm{Fs}_{2}$. The $t^{1 / 2}$ of $\mathrm{N}$ for VC ranged from 80 to 196 days for $\mathrm{Fs}_{4}$ and $\mathrm{Fs}_{2}$, respectively, in which mean $k$ of residual $\mathrm{N}$ for residues of all residues-size classes from VC was 0.0058 day $^{-1}$ (Table 2).

At 300 DAD in HC, residues-size classes with a greater degreeof-fragmentation had residual $\mathrm{N}$ of $8.8\left(\mathrm{Fs}_{1}\right)$ and $12.6\left(\mathrm{Fs}_{2}\right)$ percent points less than observed in residue-size from VC. Residual $\mathrm{N}$ in residue-size with lower degree-of-fragmentation was $2.3\left(\mathrm{Fs}_{3}\right)$ and $16.0\left(\mathrm{Fs}_{4}\right)$ percent points greater for $\mathrm{HC}$ in relation to that observed for the same residue-size classes from VC.

Reduction of residual $\mathrm{N}$ in residue-size classes from $\mathrm{HC}$ and from VC over time probably increased soil mineral N, such as ammonium and especially nitrate, which may be taken up by the plants. However, for larger residue-size, as in $\mathrm{Fs}_{3}$, both in $\mathrm{HC}$ and VC residual $\mathrm{N}$ showed a tendency of being greater than in more fragmented residues. This behavior may be explained by the lower surface area in contact with soil surface, thus affecting microbial activity, and/or because residue $\mathrm{C} / \mathrm{N}$ ratio was greater than 25 , which stimulates $\mathrm{N}$ immobilization by soil microbial population (Reinertsen et al., 1984; Cattanio et al., 2008).

Lowest percentage of residual $\mathrm{P}$ over time was observed in greatest residue-size class $\left(\mathrm{Fs}_{1}\right)$ from $\mathrm{HC}$ as compared to residues of $\mathrm{Fs}_{2}, \mathrm{Fs}_{3}$, and $\mathrm{Fs}_{4}$. At $90 \mathrm{DAD}$ mean residual $\mathrm{P}$ was $37.7 \%$, and at 300 DAD it was $25.6 \%$. The $t^{1 / 2}$ of $P$ ranged from 45 to 169 days for residues of $\mathrm{Fs}_{1}$ and $\mathrm{Fs}_{3}$, respectively, in which mean decomposition constant was $0.0086 \mathrm{day}^{-1}$ for residue-size classes from HC (Table 2). For VC, residual $\mathrm{P}$ values were greater and similar among different residue-size classes at 90 DAD when compared to the $P$ values from the HC. Mean residual P was 69.8 and $29.3 \%$ at 90 and $300 \mathrm{DAD}$, respectively. The $t^{1 / 2}$ of $\mathrm{P}$ ranged from $111\left(\mathrm{Fs}_{1}\right.$ and $\mathrm{Fs}_{3}$ ) to 140 days $\left(\mathrm{Fs}_{4}\right)$, in which mean decomposition constant was 0.0058 day $^{-1}$ for residue-size classes from VC (Table 2 ).

Comparing the two chopping mechanisms, at 300 DAD residual $\mathrm{P}$ of the more fragmented residue-size from $\mathrm{HC}\left(\mathrm{Fs}_{1}\right)$ was $9.4 \%$ points less than for same residue-size class from VC. Residual $\mathrm{P}$ in residues of $\mathrm{Fs}_{3}$ was 22.5 percent points greater for $\mathrm{HC}$ compared to the observed for same class from VC.

Residual $\mathrm{P}$ in residue-size from HC and VC over time decreased because plant-tissue $P$ is found mostly in cell vacuole in the form of inorganic P and monoesters (Giacomini et al., 2003), soluble in water and thus easily released. Other forms of residual P soluble in water, such as diesters (nucleic acids, phospholipids, and phosphoproteins), are released by microbial activity (Frossard et al., 1995; Giacomini et al., 2003). The $\mathrm{Fs}_{1}$ residue-size class, especially in the $\mathrm{HC}$, showed less residual $\mathrm{P}$ over time, probably because the contact area with soil surface is greater, which stimulates microbial activity (Hyvönen et al., 2000).

The percentage of residual $\mathrm{K}$ decreased over time in residuesize classes, from HC and from VC. Residual K among residues-size of $\mathrm{Fs}_{1}$ and $\mathrm{Fs}_{2}$ in $\mathrm{HC}$ was similar at $90 \mathrm{DAD}$, with 17.3 and $19.1 \%$, respectively. However, in VC residues with greater degree-offragmentation $\left(\mathrm{Fs}_{1}\right)$ exhibited lower residual $\mathrm{K}$ over time, in relation to less residue-size class $\left(\mathrm{Fs}_{2}, \mathrm{Fs}_{3}\right.$, and $\left.\mathrm{Fs}_{4}\right)$. At $90 \mathrm{DAD}$ residual $\mathrm{K}$ for $\mathrm{Fs}_{1}$ was $24.2 \%$, while for $\mathrm{Fs}_{3}$ it was $90.9 \%$. At $300 \mathrm{DAD}$ residual $\mathrm{K}$ was similar among residue-size classes, with a mean value of 21.9. In VC, $t^{1 / 2}$ of $\mathrm{K}$ ranged from 47 to 201 days for $\mathrm{Fs}_{1}$ and $\mathrm{Fs}_{3}$, respectively, in which mean decomposition constant was 0.0082 day $^{-1}$ (Table 2 ).

Contrasting the two chopping mechanisms, residual $\mathrm{K}$ of smaller residue-size class from $\mathrm{HC}\left(\mathrm{Fs}_{1}\right)$ was only $0.8 \%$ points less than for same class from VC. Residual $\mathrm{K}$ of $\mathrm{Fs}_{2}$ was 19.5\% points greater than same class from VC. The decrease in percentage of residual $\mathrm{K}$ in residue-size classes in $\mathrm{HC}$ and VC occurred because $\mathrm{K}$ is a cation not associated to any plant tissue structural component (Cattanio et al., 2008) and is normally found in soluble form in residues deposited on soil surface (Giacomini et al., 2003). Thus, K is easily released from residues deposited on soil surface, a process accelerated by high rainfall in the Amazon (Cattanio et al., 2008). This explains the percentages of residual K near zero at 300 DAD for residue-size classes in $\mathrm{HC}$ and, for example, in $\mathrm{Fs}_{1}$ in $\mathrm{VC}$, which are of smaller residue-size class and, consequently, have a greater surface area for contact with soil. Fast release of $\mathrm{K}$ in surface residues is in agreement with other studies undertaken in the Amazon region (Cattanio et al., 2008).

The percentage of residual $\mathrm{Ca}$ in residue-size classes from $\mathrm{HC}$ and from VC decreased over time. In $\mathrm{HC}$, in comparison with $\mathrm{Fs}_{1}$, $\mathrm{Fs}_{2}$, and $\mathrm{Fs}_{3}$ residue-size classes, the $\mathrm{Fs}_{4}$ showed greater percentage of residual $\mathrm{Ca}$, with $75.8 \%$ at 90 DAD and $29.2 \%$ at 300 DAD. The mean percentage of residual $\mathrm{Ca}$ for $\mathrm{Fs}_{1}, \mathrm{Fs}_{2}$, and $\mathrm{Fs}_{3}$ was 33.9 and $16.3 \%$ at 90 and $300 \mathrm{DAD}$, respectively. In HC, the $t^{1 / 2}$ of Ca ranged from 56 to 179 DAD for $\mathrm{Fs}_{1}$ and $\mathrm{Fs}_{4}$ residues, respectively, in which mean decomposition constant was 0.0089 day $^{-1}$ (Table 2). The percentage of residual $\mathrm{Ca}$ at $90 \mathrm{DAD}$ was greater for classes with larger residue-size $\left(\mathrm{Fs}_{3}\right.$ and $\left.\mathrm{Fs}_{4}\right)$ in relation to smaller ones $\left(\mathrm{Fs}_{1}\right.$ and $\mathrm{Fs}_{2}$ ), and similar at $300 \mathrm{DAD}$ in VC. At 90 and 300 DAD mean percentage of residual Ca was 28.3 and $15.2 \%$, respectively. The $t^{1 / 2}$ of $\mathrm{Ca}$ ranged from 33 to $74 \mathrm{DAD}$ for $\mathrm{Fs}_{2}$ and $\mathrm{Fs}_{3}$ residues, respectively, with mean decomposition constant of 0.0141 day $^{-1}$ (Table 2).

Comparing the two chopping mechanisms, only residual Ca of residues with greater degree-of-fragmentation $\left(\mathrm{Fs}_{1}\right)$ was less, by $6.6 \%$ points, in $\mathrm{HC}$ compared to VC at 300 DAD. Residual Ca in residues-size of $\mathrm{HC}$ was $1.6\left(\mathrm{Fs}_{2}\right), 7.7\left(\mathrm{Fs}_{3}\right)$, and $13.8\left(\mathrm{Fs}_{4}\right)$ percent points greater in relation to residual $\mathrm{Ca}$ in the residues-size of VC.

The Ca in plant-tissue is connected with cell-wall pectates (Serbin et al., 2009) and, thus, its release is highly associated with soil surface residue degradation by microbial population, which may be one of the possible explanations for limited release and, consequently, greater percentage of residual $\mathrm{Ca}$, i.e., in residues with greater residue-size class $\left(\mathrm{Fs}_{4}\right)$ from $\mathrm{HC}$ and even from VC. In $\mathrm{Fs}_{4}$ residue-size classes from $\mathrm{VC}$, a tendency for lower residual DM was observed. In addition, reduced release of Ca may be associated with luxury uptake of element by fungal hyphae (Cattanio et al., 2008).

The percentage of residual $\mathrm{Mg}$ in residue-size classes from $\mathrm{HC}$ and from VC decreased over time. In $\mathrm{HC}$ residual Mg was similar for residues with greater degree-of-fragmentation $\left(\mathrm{Fs}_{1}\right.$ and $\left.\mathrm{Fs}_{2}\right)$ at 
Table 3

Plant height, shoot dry matter, and yield of cassava in chopping-and-mulching of secondary-forest with horizontal (HC) and vertical (VC) rotor mechanisms.

\begin{tabular}{llll}
\hline System & Plant height $(\mathrm{cm})$ & Dry matter $\left(\mathrm{Mg} \mathrm{ha}^{-1}\right)$ & Yield $\left(\mathrm{Mg} \mathrm{ha}^{-1}\right)$ \\
\hline HC & $206 \mathrm{a}^{1}$ & $3.89 \mathrm{a}$ & $13.06 \mathrm{a}$ \\
VC & $238 \mathrm{a}$ & $2.78 \mathrm{a}$ & $12.60 \mathrm{a}$ \\
\hline
\end{tabular}

1 Mean values followed by the same lowercase letter in the column do not differ by the LSD test at $5 \%$ probability.

90 and 300 DAD. The $t^{1 / 2}$ of $\mathrm{Mg}$ was 46 and $69 \mathrm{DAD}$ for $\mathrm{Fs}_{1}$ and $\mathrm{Fs}_{2}$ residues respectively, with mean decomposition constant of 0.0125 day $^{-1}$ (Table 2). In VC residual Mg was similar among residue-size classes with mean values of $85.7 \%$ at 90 DAD and $77.2 \%$ at $300 \mathrm{DAD}$. The $t^{1 / 2}$ of $\mathrm{Mg}$ ranged from 64 to $100 \mathrm{DAD}$ for the $\mathrm{Fs}_{4}$ and $\mathrm{Fs}_{1}$ residues, respectively, with mean decomposition constant of $0.0087 \mathrm{day}^{-1}$ (Table 2). At $300 \mathrm{DAD}$ in $\mathrm{HC}$, residual $\mathrm{Mg}$ in residues with greatest degree-of-fragmentation was $14.3 \%\left(\mathrm{Fs}_{1}\right)$ and $6.9 \%\left(\mathrm{Fs}_{2}\right)$ points less than observed in residues from VC.

Decrease in the percentage of residual $\mathrm{Mg}$ of residue-size classes, in HC and VC, occurred over time and were similar among the sampling times because of partial nutrient release from cellular constituents (Crusciol et al., 2008), corresponding to rapid release phase, and part of Mg bound to structural constituents which is released more gradually over time during residue decomposition.

\subsection{Cassava yield}

Plant height, shoot biomass, and yield of cassava were not affected by land preparation systems with double vertical (VC) and horizontal (HC) rotor mechanisms (Table 3). Since there was no real control, i.e., zero residue, it is difficult to interpret the cassava yield data. In cropped area with distribution of chopped secondary-forest, Secco and Kato (2003) observed production of $14.5 \mathrm{Mg} \mathrm{ha}^{-1}$ of cassava, similar to the yield obtained in our study.

Lack of effect on crop production may occur because nutrients contained in residues are slowly released to soil, which contributes little to increased soil organic matter and nutrient availability to plants (Denich et al., 2005). Sometimes, fertilizing crops like cassava is necessary when grown in soil with secondary-forest vegetation decomposition (Kato et al., 1999; Denich et al., 2004). Kato et al. (2007), for instance, observed greater yield of cassava root in soil subjected to management through chopping-andmulching of secondary-forest vegetation combined with mineral fertilization.

\section{Conclusions}

Alternative systems of chopping-and-mulching secondaryforest vegetation with double vertical and horizontal rotor mechanisms resulted in different residue-size and residue-type, but they exhibited similar decomposition behavior and reduction of approximately $60 \%$ of initial dry matter at 90 days after distribution on soil surface.

Residue dry matter reduction was slow and 52 days would be necessary for decomposition of half the labile residue, but still maintaining a significant part of labile residue and most of recalcitrant residue of difficult decomposition on soil surface.

Release $\mathrm{N}, \mathrm{P}, \mathrm{K}, \mathrm{Ca}$ and $\mathrm{Mg}$ nutrients from plant residues diminished over time, and on each collection date was generally greater for smaller residue-size classes, but similar between chopping-and-mulching mechanisms.

Release of crop nutrients, in general, tended to be greater for smaller residue-size and similar for chopping-and-mulching mechanisms for secondary-forest vegetation management, but this difference was insufficient to affect cassava yield.

\section{References}

Adeniyi, A.S., 2010. Effects of slash and burning on soil microbial diversity and abundance in the tropical rainforest ecosystem Ondo State, Nigeria. Afr. J. Plant Sci. 4, 322-329.

Alvares, C.A., Stape, J.L., Sentelhas, P.C., Gonçalvex, J.L.M., Sparovek, G., 2013. Köppen's climate classification map for Brazil. Meteorol. Z. 22, 711-728.

Auer, C.G., Ghizelini, A.M., Pimentel, I.C., 2007. Decomposição fúngica de acículas em plantios de Pinus. Pesq. Flor. Bras. 54, 127-138.

Barlow, J., Gardner, T.A., Ferreira, L.V., Peres, C.A., 2007. Litter fall and decomposition in primary, secondary and plantation forests in the Brazilian Amazon. For. Ecol. Manage. 247, 91-97. doi:http://dx.doi.org/10.1016/j.foreco.2007.04.017.

Bayer, C., Martin-Neto, L., Mielniczuk, J., Pavinato, A., 2004. Carbon storage in labile fractions of soil organic matter in a tropical no-tillage Oxisol. Pesq. Agropec. Bras. 683. doi:http://dx.doi.org/10.1590/S0100-204X2004000700009.

Béliveau, A., Lucotte, M., Davidson, R., Lopes, L.O.C., Paquet, S., 2009. Early Hg mobility in cultivated tropical soils one year after slash-and-burn of the primary forest, in the Brazilian Amazon. Sci. Total Environ. 407, 4480-4489. doi:http:// dx.doi.org/10.1016/j.scitotenv.2009.04.012.

Bervald, C.M.P., Block, A., Reichert, J.M., Vielhaeur, K., Kato, O.R., 2007. Características e Operação de Triturador de Vegetação Secundária para o Preparo de Área Sem Queima na Amazônia Oriental. Documentos. EMBRAPA, Belém - PA.

Braz, A.M.S., Fernandes, A.R., Alleoni, L.R.F., 2013. Soil attributes after the conversion from forest to pasture in Amazon. Land Degrad. Dev. 24, 33-38. doi:http://dx. doi.org/10.1002/ldr.1100.

Cardoso Júnior, N.S., Viana, A.E.S., Matsumoto, S.N., Sediyama, T., Carvalho, F.M., 2005. Efeito do nitrogênio em características agronômicas da mandioca. Bragantia 64, 651-659. doi:http://dx.doi.org/10.1590/S000687052005000400015 .

Cattanio, J.H., Kuehne, R., Vlek, P.L.G., 2008. Organic material decomposition and nutrient dynamics in a mulch system enriched with leguminous trees in the Amazon. Rev. Bras. Cienc. Solo 32, 1073-1086. doi:http://dx.doi.org/10.1590/ S0100-06832008000300016.

Cerdà, A., 1998a. Postfire dynamics of erosional processes under mediterranean climatic conditions. Z. Geomorphol. 42, 373-398.

Cerdà, A., 1998b. Changes in overland flow and infiltration after a rangeland fire in a Mediterranean scrubland. Hydrol. Processes 12, 1031-1042. doi:http://dx.doi. org/10.1002/(SICI)1099-1085(19980615)12:7<1031::AID-HYP636>3.0.CO;2-V.

Cerdà, A., Lasanta, A., 2005. Long-term erosional responses after fire in the Central Spanish Pyrenees: 1. Water and sediment yield. Catena 60, 59-80. doi:http://dx. doi.org/10.1016/j.catena.2004.09.006.

Christensen, G.D., Simpson, W.A., Yonger, J.J., Baddor, L.M., Barrett, F.F., Melton, D.M., Beachey, E.H., 1985. Adherence of coagulase-negative staphylococci to plastic tissue culture plates: a quantitative model for the adherence of staphylococci to medical devices. J. Clin. Microbiol. 22, 996-1006.

Cochrane, T.T., Sanchez, P.A., 1982. Land resources, soils and their management in the Amazon region: a state of knowledge report. International Conference on Amazonian Agriculture and Land use Research, 1. Cali, 1980. Amazonian: Agriculture and Land use Research; Proceedings, Cali, CIAT, pp. 37-209.

Comte, I., Davidson, R., Lucotte, M., Carvalho, C.J.R., Oliveira, F.A., Silva, B.P., Rousseau, G.X., 2012. Physicochemical properties of soils in the Brazilian Amazon following fire-free land preparation and slash-and-burn practices. Agric. Ecosyst. Environ. 156, 108-115. doi:http://dx.doi.org/10.1016/j. agee.2012.05.004.

Crusciol, A.C., Moro, E., Lima, V.E., Andreotti, M., 2008. Taxa de decomposição e de liberação de macronutrientes da palhada de aveia preta em plantio direto. Bragantia 32, 481-489.

Davidson, E.A., Sá, T.D.A., Carvalho, C.J.R., Figueiredo, R.O., Kato, M.S.A., Kato, O.R., Ishida, F.Y., 2008. An integrated greenhouse gas assessment of an alternative to slash-and-burn agriculture in eastern Amazonia. Global Change Biol. 14, 998-1007. doi:http://dx.doi.org/10.1111/j.1365-2486.2008.01542.x.

Denich, M. Vielhauer, K., Kato, M.S.A., Block, A., Kato, O., Sá, T.D.A., Lücke, W., Vlek, P. L.G., 2004. Mechanized land preparation in forest-based fallow systems: the experience from Eastern Amazonia. Agrofor. Syst. 61, 91-106. doi:http://dx.doi. org/10.1023/B:AGFO.0000028992.01414.2a.

Denich, M., Vlek, P.L.G., Sá, T.D.A., Vielhauer, K., Lucke, W.G., 2005. A concept for the development of fire-free fallow management in the Eastern Amazon, Brazil. Agric. Ecosyst. Environ. 58. doi:http://dx.doi.org/10.1016/j.agee.2005.05.005.

Diniz, T.D.A.S., 1991. Climatic characteristics of the eastern Amazon region. Studies on the utilization and conservation of soil in the eastern amazon region. BelémEMBRAPA-CPATU-GTZ, Belém, pp. 3-13 (Documentos, 40).

Doneda, A., Aita, C., Giacomini, S.J., Miola, E.C.C., Giacomini, D.A., Schirmann, J., Gonzatto, R., 2012. Fitomassa e decomposição de resíduos de plantas de cobertura puras e consorciadas. Rev. Bras. Cienc. Solo 36, 1714-1723. doi:http:// dx.doi.org/10.1590/S0100-06832012000600005.

Empresa Brasileira de Pesquisa Agropecuária - EMBRAPA, 2006. Sistema Brasileiro de Classificação de Solos. Brasília, 412 p.

Empresa Brasileira de Pesquisa Agropecuária - EMBRAPA, 1997. Manual de métodos de análise de solo, second ed. Embrapa - SNLCS, Rio de Janeiro, pp. 212.

Espíndola, J.A.A., Guerra, J.G.M., Almeida, D.L., Teixeira, M.G., Urquiaga, S., 2006. Decomposição e liberação de nutrientes acumulados em leguminosas herbáceas perenes consorciadas com bananeira. Rev. Bras. Cienc. Solo 30, 321-328. doi:http://dx.doi.org/10.1590/S0100-06832006000200012.

Farella, N., Davidson, R., Lucotte, M., Daigle, S., 2007. Nutrient and mercury variations in soils from family farms of the Tapajós region (Brazilian Amazon): 
recommendations for better farming. Agric. Ecosyst. Environ. 120, 449-462. doi: http://dx.doi.org/10.1016/j.agee.2006.11.003.

Farella, N., Lucotte, M., Louchouarn, P., Roulet, M., 2001. Deforestation modifying terrestrial organic transport in the Rio Tapajós, Brazilian Amazon. Org. Geochem. 32, 1443-1458. doi:http://dx.doi.org/10.1016/S0146-6380(01)00103-6.

Ferreira, S.J.F., Luizão, F.J., Mello-Ivo, W.M.P., Ross, S.M., Biot, Y., 2002. Propriedades físicas do solo após extração seletiva de madeira na Amazônia Central. Acta Amaz. 32, 449-466.

Frossard, E., Frossard, M., Hedley, M.J., Matherell, A., 1995. Reactions controlling the cycling of P in soil. In: Tiessnm, H. (Ed.), Phosphorus in the Global Environment: Transfers, Cycles and Management. John Wiley \& Sons Ltd., Chichester, pp. 107-146.

García-Orenes, F., Roldán, A., Mataix-Solera, J., Cerdà, A., Campoy, M., Arcenegui, V., Caravaca, F., 2012. Soil structural stability and erosion rates influenced by agricultural management practices in a semi-arid Mediterranean agroecosystem. Soil Use Manage. 28, 571-579. doi:http://dx.doi.org/10.1111/j.14752743.2012.00451.x.

Giacomini, S.J., Aita, C. Vendruscolo, E.R.O., Cubilla, M., Nicoloso, R.S., Fries, M.R. 2003. Matéria seca, relação $\mathrm{C} / \mathrm{N}$ e acúmulo de nitrogênio, fósforo e potássio em misturas de plantas de cobertura de solo. Rev. Bras. Cienc. Solo 27, 325-334. doi: http://dx.doi.org/10.1590/S0100-06832003000200012.

Guénon, R., Vennetier, M., Dupuy, N., Roussos, S., Pailler, A., Gros, R., 2013. Trends in recovery of Mediterranean soil chemical properties and microbial activities after infrequent and frequent wildfires. Land Degrad. Dev. 24, 115-128. doi: http://dx.doi.org/10.1002/ldr.1109.

Hölscher, D., Ludwig, B., Möller, R.F., Fö1ster, H., 1997a. Dynamic of soil chemical parameters in shifting agriculture in the Eastern Amazon. Agric. Ecosyst. Environ. 66, 153-163. doi:http://dx.doi.org/10.1016/S0167-8809(97)00077-7.

Hölscher, D., Möller, R.F., Denich, M., Fölster, H., 1997b. Nutrient input-output budget of shifting agriculture in Eastern Amazonia. Nutr. Cycling Agroecosyst. 47, 49-57. doi:http://dx.doi.org/10.1007/BF01985718.

Hunt, H.W., Ingham, E.R., Coleman, D.C., Reid, C.P.P., 1988. Nitrogen limitation of production and decomposition in prairie, mountain meadow, and pine forest. Ecology 69, 1009-1016. doi:http://dx.doi.org/10.2307/1941256.

Hyvönen, R., Olsson, B.A., Lundkvist, H., Staaf, H., 2000. Decomposition and nutrient release from Picea abies (L.) Karst. and Pinus sylvestris L. logging residues. For. Ecol. Manage. 126, 97-112. doi:http://dx.doi.org/10.1016/S0378-1127(99) 00092-4.

Jiménez, M.N., Fernández-Ondoño, E., Ripoll, M.A., Castro-Rodríguez, J., Huntsinger, L., Navarro, F.B., 2013. Stones and organic mulches improve the Quercus ilex L. afforestation success under Mediterranean climatic conditions. Land Degrad. Dev. doi:http://dx.doi.org/10.1002/ldr.2250.

Kato, M.S.A., Kato, O.R., Denich, M., Vlek, P.L.G., 1999. Fire-free alternatives to slashand-burn for shifting cultivation in the eastern Amazon region: the role of fertilizers. Field Crop. Res. 62, 225-237. doi:http://dx.doi.org/10.1016/S03784290(99)00021-0.

Kato, O.R., Kato, M.A.S., Carvalho, C.J.R., Figueiredo, R.O., Camarao, A.P., Sá, T.O.D.A., 2007. Plantio direto na capoeira: uma alternativa com base no manejo de recursos naturais. Sistema Plantio Direto e Controle de Erosão no Estado do Acre. Embrapa Acre, Rio Branco - AC, pp. 79-111.

Kato, O.R., Kato, M.A.S., Jesus, C.C., Rendeiro, A.C., 2002. Época de preparo de área e plantio de milho no sistema de corte e trituração no município de Igarapé-Açu, Pará. Comunicado Técnico. EMBRAPA, Belém - PA, pp. 64.

Kanashiro, M., Denich, M., 1998. Possibilidades de utilização e manejo adequado de áreas alteradas e abandonadas na Amazônia brasileira. BrasíliaMCT/CNPq, pp. 157 (Studies of Human Impact on Forests and Floodplains in the Tropics SHIFT).

Lasanta, A., Cerdà, A., 2005. Long-term erosional responses after fire in the Central Spanish Pyrenees: 2. Solute release. Catena 60, 80-101. doi:http://dx.doi.org/ 10.1016/j.catena.2004.09.005

Lee, J.-W., Park, C.-M., Rhee, H., 2013. Revegetation of decomposed granite roadcuts in Korea: developing digger, evaluating cost effectiveness, and determining dimension of drilling holes, revegetation species, and mulching treatment. Land Degrad. Dev. 24, 591-604. doi:http://dx.doi.org/10.1002/ldr.2248.

Liao, J.H., Wang, H.H., Tsai, C.C., Hseu, Z.Y., 2006. Litter production, decomposition and nutrient return of uplifted coral reef tropical forest. For. Ecol. Manage. 235, 174-185. doi:http://dx.doi.org/10.1016/j.foreco.2006.08.010.
Milder, A.I., Fernández-Santos, B., Martínez-Ruiz, C., 2012. Colonization patterns of woody species on lands mined for coal in Spain: Preliminary insights for forest expansion. Land Degrad. Dev. 24, 39-46. doi:http://dx.doi.org/10.1002/ ldr.1101.

Mukhopadhyay, S., Maiti, S.K., 2014. Soil $\mathrm{CO}_{2}$ flux in grassland, afforested land and reclaimed coalmine overburden bumps: a case study. Land Degrad. Dev. 25, 216-227. doi:http://dx.doi.org/10.1002/ldr.1161.

Musvoto, C., Campbell, B.M., Kirchmann, H., 2000. Decomposition and nutrient release from mango and miombo woodland litter in Zimbabwe. Soil Biol. Biochem. 32. doi:http://dx.doi.org/10.1016/S0038-0717(00)00023-7 1111:1119.

Paul, E.A., Clark, F.E., 1989. Soil Microbiology and Biochemistry. Academic Press, San Diego, pp. 275.

Prats, S.A., Malvar, M.C., Simões-Vieira, D.C., McDonald, L., Keizer, J.J., 2013. Effectiveness of hydro-mulching to reduce runoff and erosion in a recently burnt pine plantation in central Portugal. Land Degrad. Dev. doi:http://dx.doi. org/10.1002/ldr.2236.

Pypers, P., Bimponda, W., Lodi-Lama, J.P., Lele, B., Malumba, R., Kachaka, C., Boeckx, P., Merckx, R., Vanlauwe, B., 2012. Combining mineral fertilizer and green manure for increased, profitable Cassava production. Agron. J. 104, 178-187. doi: http://dx.doi.org/10.2134/agronj2011.0219.

Reichert, J.M., Bervald, C.M.P., Rodrigues, M.F., Kato, O.R., Reinert, D.J., 2014. Mechanized land preparation in eastern Amazon in fire-free forest-based fallow systems as alternatives to slash-and-burn practices: hydraulic and mechanical soil properties. Agric. Ecosyst. Environ. 192, 47-60. doi:http://dx.doi.org/ 10.1016/j.agee.2014.03.046.

Reinertsen, S.A., Elliot, L.F., Cochran, V.L., Campbell, G.S., 1984. Role of available carbon and nitrogen in determining the rate of wheat straw decomposition. Soil Biol. Biochem. 16, 459-464. doi:http://dx.doi.org/10.1016/0038-0717(84) 90052-X.

Ruivo, M.L.P., Monteiro, K.F.G., Silva, R.M., Silveira, I.M., Quaresma, H.D.A.B., Sa, L.D. A., Prost, M.T.C., 2007. Gestão florestal e implicações sócio-ambientais na Amazônia Oriental (Estado do Pará). Oecol. Bras. 11, 481-492. doi:http://dx.doi. org/10.4257/oeco.2007.1104.02.

Santos, E.M.R., Franklin, E., Luizão, F.J., 2008. Litter manipulation and associated invertebrate fauna in secondary forest, central Amazonia, Brazil. Acta Oecol. 34 274-284. doi:http://dx.doi.org/10.1016/j.actao.2008.05.011.

SAS Institute Inc., SAS/STAT, 1990. User's Guide, Version G, fourth ed. SAS Institute Inc., Cary: NC.

Secco, N.B., Kato, M.S.A., 2003. Efeito do método de preparo de área e da intensificação do cultivo na produção das culturas anuais. Seminário de Iniciação Científica da UFRA, I Seminário de Iniciação Científica da EMBRAPACPATU, VII. Anais, Belém: UFRA-EMBRAPA/CNPq, 2003. CD-ROM.

Serbin, G., Daughtry, G.S.T., Hunt, G.R., Reeves, J.B., Brown, D.J., 2009. Effects of soil composition and mineralogy on remote sensing of crop residue cover. Remote Sens. Environ. 113, 224-238. doi:http://dx.doi.org/10.1016/j.rse.2008.09.004.

Sommer R, Vlek, P. G Sá, T. A., Vielhauer, K, Coelho, R.D.R, Folster, H., 2004. Nutrient balance of shifting cultivation by burning or mulching in the Eastern Amazon - evidence for subsoil nutrient accumulation. Nutr. Cycling Agroecosyst. 271. doi:http://dx.doi.org/10.1023/B:FRES.0000019470.93637.54.

Tedesco, M.J., Gianello, C., Bissani, C.A., Bohnen, H., Volkweiss, S.J., 1995. Análises de solo, plantas e outros materiais. Porto Alegre, Departamento de Solos, UFRGS, pp. 174.

Tejada, M., Benítez, C., 2014. Effects of crushed maize straw residues on soil biological properties and soil restoration. Land Degrad. Dev. 25, 501-509. doi: http://dx.doi.org/10.1002/ldr.2316.

USDA - Soil Survey Staff, Soil Taxonomy - a basic system of soil classification for making and interpreting soil survey, 1999, second ed. Washington; 871.

Vasconcelos, H.L., Laurance, W.F., 2005. Influence of habitat, litter type, and soil invertebrates on leaf-litter decomposition in a fragmented Amazonian landscape. Oecologia 144, 456-462. doi:http://dx.doi.org/10.1007/s00442-0050117-1.

Wästerlund, I., 1994. Enviromentally soft machines. Small Scale For. 1, 13-15.

Wieder, R.K., Lang, G.E., 1982. A critique of the analytical methods used in examining decomposition data obtained from litter bags. Ecology 63, 1636-1642. doi: http://dx.doi.org/10.2307/1940104. 